\title{
Efficient organic carbon burial in the Bengal fan sustained by the Himalayan erosional system
}

\author{
Valier Galy ${ }^{1}$, Christian France-Lanord ${ }^{1}$, Olivier Beyssac ${ }^{2}$, Pierre Faure $^{3}$, Hermann Kudrass ${ }^{4}$ \& Fabien Palhol ${ }^{1}$ \\ ${ }^{1}$ Centre de Recherches Pétrographiques et Géochimiques, BP 20, 54501 Vandoeuvre-lès-Nancy, France. Present \\ address: Woods Hole Oceanographic Institution,360 Woods Hole Rd, Woods Hole, MA 02543, USA \\ ${ }^{2}$ Laboratoire de Géologie, Ecole Normale Supérieure, CNRS-UMR 8538, 24 rue Lhomond, F-75005 Paris Cedex \\ 5, France. ${ }^{3}$ UMR-CNRS 7566 G2R, Université Henri Poincaré, BP 239, 54506 Vandoeuvre-les-Nancy, France. \\ ${ }^{4}$ Federal Institute for Geosciences and Natural Resources (BGR), 30655 Hannover, Germany.
}

Continental erosion controls atmospheric carbon dioxide levels on geological timescales through silicate weathering, riverine transport and subsequent burial of organic carbon in oceanic sediments ${ }^{1}$. The efficiency of organic carbon deposition in sedimentary basins is however limited by the organic carbon load capacity of the sediments and organic carbon oxidation in continental margins. At the global scale, previous studies have suggested that about 70 per cent of riverine organic carbon is returned to the atmosphere, such as in the Amazon basin ${ }^{2-4}$. Here we present a comprehensive organic carbon budget for the Himalayan erosional system, including source rocks, river sediments and marine sediments buried in the Bengal fan. We show that organic carbon export is controlled by sediment properties, and that oxidative loss is negligible during transport and deposition to the ocean. Our results indicate that 70 to 85 per cent of the organic carbon is recent organic matter captured during transport, which serves as a net sink for atmospheric carbon dioxide. The amount of organic carbon deposited in the Bengal basin represents about 10 to 20 per cent of the total terrestrial organic carbon buried in oceanic sediments. High erosion rates in the Himalayas generate high sedimentation rates and low oxygen availability in the Bay of Bengal that sustain the observed extreme organic carbon burial efficiency. Active orogenic systems generate enhanced physical erosion and the resulting organic carbon burial buffers atmospheric carbon dioxide levels, thereby exerting a negative feedback on climate over geological timescales.

Photosynthesis of organic matter is a major pathway for consumption of atmospheric $\mathrm{CO}_{2}$. Although most photosynthetic organic carbon $\left(\mathrm{C}_{\text {org }}\right)$ is re-oxidized and returns to the atmosphere, a small fraction is buried in sedimentary basins and stored over geological timescales ${ }^{5}$. This burial represents the second largest atmospheric $\mathrm{CO}_{2}$ sink (after silicate weathering coupled to carbonate precipitation) and contributes to long-term climate 
regulation ${ }^{6}$. Continental erosion exerts a primary control on $\mathrm{C}_{\text {org }}$ burial through sediment transport and detrital deposition in sedimentary basins. However, assessing the role of continental erosion in this part of the $\mathrm{C}$ cycle is complex, as several processes control its efficiency. First, $\mathrm{C}_{\text {org }}$ transported by rivers is composed of both recent organic matter and fossil refractory $\mathrm{C}_{\mathrm{org}}$ derived from erosion of carbonaceous rocks. Erosion-burial of the latter has no effect on the long term $\mathrm{C}$ cycle and it is therefore necessary to determine its proportion. Second, it is generally believed that $\sim 70 \%$ of $\mathrm{C}_{\text {org }}$ exported by global rivers (for example, the Amazon) is oxidized in the continental margins before burial and thus returns to the atmosphere ${ }^{2-4}$. Last, assessing the riverine $C_{\text {org }}$ flux is not straightforward, because the $\mathrm{C}_{\text {org }}$ content of sediment is highly variable owing to transport segregation processes. Understanding the impact of continental erosion on the $\mathrm{C}_{\text {org }}$ cycle requires identification of the controls on the flux of riverine $\mathrm{C}_{\text {org }}$, the proportion of rock-derived fossil $\mathrm{C}_{\text {org }}$ and the burial efficiency.

Himalayan erosion generates the largest flux of sediments to the oceans. Today, this represents between 1 and 2 billion tons of sediments exported each year from the Himalayas through the Ganges-Brahmaputra (G-B) system and buried in the Bengal fan sedimentary unit $^{7-9}$. The total $\mathrm{C}_{\text {org }}$ concentration (TOC) in G-B fluvial sediments was hitherto estimated using only surface suspended sediments and without correction for the fossil $\mathrm{C}_{\text {org }}$ contribution $^{10,11}$. Over the past $15 \mathrm{Myr}$, the Bengal fan has buried an average of about $0.6 \times 10^{12} \mathrm{~mol} \mathrm{C}_{\text {org }} \mathrm{yr}^{-1}$, that is, $15 \%$ of the global burial flux ${ }^{12}$. The Himalayas are thus a key locality for isolating the role of major orogens on the $\mathrm{C}$ cycle.

A major sample set covering the whole basin from the Himalayas to the distal part of the Bengal fan has been analysed for $\mathrm{C}_{\mathrm{org}},{ }^{14} \mathrm{C}$ and chemistry (Supplementary Tables 1 and 2). The two major rivers (Ganges and Brahmaputra) and their confluence (Lower Meghna) were sampled during three monsoon seasons when $\sim 95 \%$ of the sediment flux is exported ${ }^{13}$ (Fig. 1, Methods). Bed loads and depth profiles of suspended sediments were collected to integrate the total sediment variability. Simultaneous acoustic Doppler current profiler measurements were performed in order to characterize the hydrodynamic conditions. The Bengal fan sedimentary units are documented by subsurface sediments cored in the shelf, in the mid-fan active channel-levee system and in the distal part of the fan during RV Sonne cruise SO93 in $1994^{14}$ (Fig. 1). Detailed study of the modern rivers and their complements in the sedimentary record allows us to quantify: (1) the Himalayan $C_{\text {org }}$ flux, (2) the proportion of rock-derived fossil $\mathrm{C}_{\mathrm{org}}$ and (3) the terrestrial $\mathrm{C}_{\mathrm{org}}$ burial efficiency. 
In the G-B system, sediments have a wide range of composition owing to differentiation during transport under hydrodynamic forces. Sediment concentrations increase, while flow velocities decrease, with depth (Supplementary Fig. 1). Suspended sediments are fine-grained and clay-rich in surface water, but become coarser and quartz-rich at depth; bed sediments are sandy and enriched in quartz. TOC varies from $0.03 \%$ to $0.82 \%$ and is remarkably well correlated with chemical composition; all G-B sediments define a positive correlation between TOC and $\mathrm{Al} / \mathrm{Si}$ ratio (Fig. 2). This trend mostly expresses co-variation of TOC with grain size and mineralogy, as $\mathrm{Al} / \mathrm{Si}$ increases with the proportion of aluminous and fine-grained minerals ${ }^{8}$. Individually, the Ganges, the Brahmaputra and the Lower Meghna define comparable trends, indicating identical $\mathrm{C}_{\text {org }}$ loading (Fig. 2). In the G-B system, mineral particles and $\mathrm{C}_{\text {org }}$ appear to have a similar response to hydrodynamic sorting, indicating a tight physical association between these components, either at the grain scale $\left(\mathrm{C}_{\text {org }}\right.$ sorption on minerals surfaces $\left.{ }^{15}\right)$ or at larger scale (formation of $\mathrm{C}_{\text {org }}$-mineral aggregates ${ }^{16}$ ). A consequence of the gradient in TOC is that earlier estimates of $\mathrm{C}_{\text {org }}$ fluxes based on surface suspended sediment data were overestimated ${ }^{10,11}$. Thus, assessing the $\mathrm{C}_{\text {org }}$ flux requires the mean sediment composition transported by the river to be calculated. With our data, the integrated suspended sediment TOC can be estimated by integrating TOC gradient, sediment concentration and flow velocity over the whole river depth. For the Lower Meghna before its discharge into the Bay of Bengal (Fig. 1), we calculate an integrated TOC of $0.41 \pm 0.04 \%$. In comparison, bed sediments have low TOC with an average value of $0.05 \%$, consistent with their high proportion of quartz.

$\mathrm{C}_{\text {org }}$ transported by rivers is a mix of inherited fossil $\mathrm{C}_{\text {org }}\left(\mathrm{FC}_{\mathrm{org}}\right)$ derived from erosion of carbonaceous rocks, and different sources of recent $\mathrm{C}_{\text {org }}\left(\mathrm{RC}_{\text {org }}\right)$ that include pre-aged soil $\mathrm{C}_{\text {org }}$ and fresh plant debris. As $\mathrm{FC}_{\text {org }}$ burial has no effect on the long-term atmospheric $\mathrm{CO}_{2}$ content, its proportion must be determined. We measured ${ }^{14} \mathrm{C}$ concentrations of acid-insoluble $\mathrm{C}_{\text {org }}$ composed of $\mathrm{FC}_{\text {org }}$ that has no ${ }^{14} \mathrm{C}\left(\Delta{ }^{14} \mathrm{C}=-1,000 \%\right)$ and $\mathrm{RC}_{\text {org }}$ that is enriched in ${ }^{14} \mathrm{C}$ (ref. 17). $\Delta^{14} \mathrm{C}$ ranges from $-814 \%$ to $-215 \%$ (13.4 to $2.0 \mathrm{kyr}$ ) and co-varies with TOC; Ganges, Brahmaputra and Lower Meghna sediments define independent but similar trends. This reflects mixing between bed sediments dominated by $\mathrm{FC}_{\mathrm{org}}$ and surface suspended sediments dominated by $\mathrm{RC}_{\text {org }}$ (Fig. 3). The $\mathrm{RC}_{\text {org }} \Delta \Delta^{14} \mathrm{C}$ is unknown, as it is derived from sources of variable ages. Surface suspended sediments constrain minimum $\Delta^{14} \mathrm{C}$ values for the $\mathrm{RC}_{\text {org }}$ of each river. $\Delta^{14} \mathrm{C}$ of $\mathrm{RC}_{\text {org }}$ must be higher, as $\mathrm{FC}_{\text {org }}$ has been detected in these surface sediments by optical and Raman spectroscopy methods (Supplementary Figs 3 and 4, 
Supplementary Discussion). Therefore, the highest measured $\Delta{ }^{14} \mathrm{C}$ sets the minimum $\mathrm{FC}_{\text {org }}$ to $14 \%$ in average suspended sediment and $42 \%$ in bed sediment. On the basis of Himalayan river gravel and bedrock ${ }^{10,12,18}$ data (Supplementary Table 1, Supplementary Fig. 2), average $\mathrm{C}_{\text {org }}$ content in the source rocks is between $0.05 \%$ and $0.08 \%$. Using the TOC versus $\mathrm{Al} / \mathrm{Si}$ relationship (Fig. 2) and assuming there is no fossil $\mathrm{C}_{\text {org }}$ oxidation during erosion and transport, we can limit the maximum proportion of $\mathrm{FC}_{\mathrm{org}}$ to $20 \%$ in average suspended sediment and to $100 \%$ in bed sediment. Combining the $\mathrm{C}_{\text {org }}$ content in source rocks with $\Delta^{14} \mathrm{C}$ constraints, we conservatively estimate that $\mathrm{FC}_{\mathrm{org}}$ represents $10-20 \%$ of $\mathrm{TOC}$ in suspended sediments and $40-100 \%$ of TOC in bed sediments.

Suspended sediment fluxes have been measured for the Ganges and the Brahmaputra, and the average total flux is around $1 \times 10^{9} \mathrm{t} \mathrm{yr}^{-1}$ (ref. 13). The flux of bed sediment is not directly measured, but geochemical mass balance implies that bed sediment flux plus floodplain sequestration are almost equal to the suspended sediment flux ${ }^{8}$. Taking into account these sediment fluxes, we estimate that the G-B system delivers $(3.1 \pm 0.3) \times 10^{11} \mathrm{~mol} \mathrm{yr}^{-1}$ of $\mathrm{RC}_{\text {org }}$ to the Bay of Bengal.

Quantifying the corresponding $\mathrm{CO}_{2}$ uptake requires determination of the proportion of this $\mathrm{RC}_{\text {org }}$ that is preserved and effectively buried in the Bengal fan. Sediment delivery to the Bengal delta shelf and active channel-levee system ${ }^{14}$, which directly reflects the input of the G-B and their sources, has been stable over the past $20 \mathrm{kyr}$, as shown by constant $\mathrm{Sr}$ and $\mathrm{Nd}$ isotopic ratios ${ }^{19}$. In these sediments, TOC and $\mathrm{Al} / \mathrm{Si}$ define a positive linear correlation statistically identical to that defined by G-B sediments (Fig. 4). It indicates similar $\mathrm{C}_{\text {org }}$ loads for river and marine sediments. The relative abundances of terrestrial and marine biomarkers as well as their stable isotopic compositions show that $\mathrm{C}_{\text {org }}$ is largely dominated by terrestrial matter (Supplementary Table 3, Supplementary Fig. 5, Supplementary Discussion), as already observed for ancient Bengal fan sediments ${ }^{20-22}$. Therefore, the terrestrial $\mathrm{C}_{\text {org }}$ loading of Bengal fan sediments roughly equals that of G-B river sediments. The Bengal fan appears to be able to preserve and bury terrestrial $\mathrm{C}_{\text {org }}$ that is exported by the G-B system. This strongly contrasts with other active margins where the burial efficiency is much lower and limited to $\sim 30 \%$ (refs $2-4$ ).

This extreme burial efficiency probably derives from the transport dynamic, with rapid sediment accumulation on the delta shelf (up to $30 \mathrm{~cm} \mathrm{yr}^{-1}$; ref. 23). In shallow water, where $\mathrm{C}_{\text {org }}$ oxidation is theoretically most efficient, $\mathrm{C}_{\text {org }}$ is protected from oxidation by quick burial under a thick layer of fresh sediments. Typical $\mathrm{O}_{2}$ penetration depth in such sediments 
is only a few centimetres ${ }^{24}$, that is, the same order of magnitude as the Bengal shelf annual accumulation $^{23}$. Therefore, $\mathrm{C}_{\text {org }}$ exposure time to $\mathrm{O}_{2}$ is only a few years or so, insufficient for effective $\mathrm{C}_{\text {org }}$ oxidation. Sediments are finally transferred to the deep-water zone by turbiditic currents and deposited in channel-levee systems ${ }^{25,26}$. Identical $\mathrm{C}_{\text {org }}$ loading in the shelf, active channel-levee and mid-deep fan sediments (Supplementary Fig. 6) indicates that $\mathrm{C}_{\text {org }}$ oxidation during sediment transfer from shelf to deep ocean is negligible. In addition, river discharge and precipitation are responsible for a negative salinity anomaly, and maintain stratified waters in the Bay of Bengal ${ }^{27,28}$. Combined with high productivity sustained by high nutrient flux delivered by the G-B, this generates an extended $\mathrm{O}_{2}$ minimum zone and generally low $\mathrm{O}_{2}$ concentrations in the Bay of $\mathrm{Bengal}^{27,28} \cdot \mathrm{C}_{\text {org }}$ oxidation is thus limited by both short exposure to, and low availability of, $\mathrm{O}_{2}$.

Climatic and tectonic factors produce high physical erosion rates and a major influx of particles and nutrients to the ocean that favour long-term $\mathrm{C}_{\text {org }}$ burial. This is characteristic of the Himalayan basin and is also true for other comparable basins, such as Oceania, that generate comparable sediment influx with high burial efficiency ${ }^{9,29}$. Uplift and erosion result in rapid sediment accumulation, which favours $C_{\text {org }}$ preservation with globally significant fluxes. Active orogenesis affects the export and burial of $\mathrm{C}_{\text {org }}$ for periods of $10^{6}-10^{7}$ years and tends to buffer long-term atmospheric $\mathrm{CO}_{2}$ and $\mathrm{O}_{2}$ levels.

\section{METHODS SUMMARY}

\section{Sampling}

Detailed sampling of the Ganges, Brahmaputra and Lower Meghna was performed during the 2002, 2004 and 2005 monsoons in Bangladesh. Suspended sediments were taken at different depths in the river channel and bedload was dredged from the bottom of the river. Marine sediments were taken from short cores drilled in the Bengal shelf, channel-levee system and deep-sea fan by the RV Sonne in 1994 (cruise SO 93).

\section{Organic carbon analyses}

Before organic carbon content and isotopic measurements, sediments were leached with $\mathrm{HCl}$ (4 wt $\%$ ) at $80{ }^{\circ} \mathrm{C}$ in order to remove any trace of carbonate. TOC and $\delta^{13} \mathrm{C}$ of bulk $\mathrm{C}_{\text {org }}$ were measured by elemental analyser-isotope ratio mass spectrometer (EA-IRMS) on a modified EuroVector EuroEA3028-HT coupled with a GV Isoprime. The overall $2 \sigma$ uncertainties associated with the TOC and $\delta^{13} \mathrm{C}$ of bulk $\mathrm{C}_{\mathrm{org}}$ determination are $0.03 \%$ and $0.25 \%$, respectively. ${ }^{14} \mathrm{C}$ measurements were performed on the LMC14 (Gif sur Yvette) AMS 
national facility. After soluble $\mathrm{C}_{\text {org }}$ extraction with dichloromethane, n-alkane relative abundances were determined on a HP 5890 gas chromatograph-mass spectrometer (GC-MS) and compound specific $\delta^{13} \mathrm{C}$ were measured on a GV-Isoprime gas chromatograph-isotope ratio mass spectrometer GC-IRMS.

\section{Fossil organic carbon detection}

Fossil organic carbon was identified and characterized by Raman microspectroscopy and high-resolution transmission electron microscopy (HRTEM). Raman spectra were obtained on untreated raw sediments with a Renishaw INVIA Reflex Raman micro-spectrometer at the Laboratoire de Géologie of the Ecole Normale Supérieure, Paris, France. HRTEM was performed on a JEOL 2010 microscope with an acceleration voltage of $200 \mathrm{kV}$, after concentration of carbonaceous material by $\mathrm{HCl} / \mathrm{HF}$ acid treatment at low temperature (below $\left.70{ }^{\circ} \mathrm{C}\right)$.

Received 15 February; accepted 11 September 2007; doi:10.1038/nature06273.

$<$ jrn $>1$. Hayes, J. M., Strauss, H. \& Kaufman, A. J. The abundance of ${ }^{13} \mathrm{C}$ in marine organic matter and isotopic fractionation in the global biogeochemical cycle of carbon during the past 800 Ma. Chem. Geol. 161, 103-125 (1999). </jrn>

$<\mathrm{jrn}>2$. Burdige, D. J. Burial of terrestrial organic matter in marine sediments: A reassessment. Glob. Biogeochem. Cycles 19, GB4011, 1-7 (2005).</jrn>

<unknown>3. Hedges, J. I., Keil, R. G. \& Benner, R. What happens to terrestrial organic matter in the ocean? Org. Geochem. 27, 195-212 (1997).</unknown>

$<$ jrn $>4$. Schlünz, B. \& Schneider, R. R. Transport of terrestrial organic carbon to the oceans by rivers: Re-estimating flux and burial rates. Int. J. Earth Sci. 88, 599-606 $(2000) .</ j r n>$

$<\mathrm{edb}>5$. Mackenzie, F. T. in Flux of Organic Carbon by Rivers to the Ocean (eds Likens, G. E. et al.) 360-384 (US Department of Energy, Washington DC, 1981). $</$ edb $>$

$<\mathrm{jrn}>6$. Berner, R. A. Atmospheric $\mathrm{CO}_{2}$ levels over Phanerozoic time. Science 249, 1382$1386(1990) .</ j \mathrm{rn}>$

$<$ jrn> 7. Curray, J. R., Emmel, F. J. \& Moore, D. G. The Bengal Fan: morphology, geometry, stratigraphy, history and processes. Mar. Petrol. Geol. 19, 1191-1223 (2003).</jrn> 
$<$ jrn $>8$. Galy, A. \& France-Lanord, C. Higher erosion rates in the Himalaya: Geochemical constraints on riverine fluxes. Geology 29, 23-26 (2001). </jrn>

$<$ jrn $>9$. Milliman, J. D. \& Syvitski, P. M. Geomorphic/tectonic control of sediment discharge to the ocean: The importance of small mountainous rivers. J. Geol. 100, 525-544 (1992). $</$ jrn $>$

$<$ unknown>10. Aucour, A.-M., France-Lanord, C., Pedoja, K., Pierson-Wickmann, A.C. \& Sheppard, S. M. F. Fluxes and sources of particulate organic carbon in the Ganga-Brahmaputra river system. Glob. Biogeochem. Cycles 20, GB2006, 1-12 (2006). $<$ /unknown $>$

$<\mathrm{edb}>11$. Subramanian, V. \& Ittekkot, V. in Biogeochemistry of Major World Rivers (eds Degens, E. T., Kempe, S. \& Richey, J. E.) 157-168 (1991).</edb>

$<$ jrn $>$ 12. France-Lanord, C. \& Derry, L. A. Organic carbon burial forcing of the carbon cycle from Himalayan erosion. Nature 390, 65-67 (1997). $<$ jrn $>$

$<$ unknown>13. RSP Spatial Representation and Analysis of Hydraulic and Morphological Data (Report No. FAP 24, 1996).</unknown>

$<$ jrn>14. Ittekkot, V., Kudrass, H. R., Quadfasel, D. \& Unger, D. Bay of Bengal. Deepsea Res. II 50, 853-1053 (2003). $</$ jrn $>$

$<$ jrn $>15$. Hedges, J. I. \& Keil, R. G. Sedimentary organic matter preservation: An assessment and speculative synthesis. Mar. Chem. 49, 81-115 (1995). </jrn>

$<$ jrn $>$ 16. Wagai, R. \& Mayer, L. M. Sorptive stabilization of organic matter in soils by hydrous iron oxides. Geochim. Cosmochim. Acta 71, 25-35 (2007).</jrn>

<jrn>17. Drenzek, N. J., Montlucon, D. B., Yunker, M. B., Macdonald, R. W. \& Eglinton, T. I. Constraints on the origin of sedimentary organic carbon in the Beaufort Sea from coupled molecular ${ }^{13} \mathrm{C}$ and ${ }^{14} \mathrm{C}$ measurements. Mar. Chem. 103, 146-162 (2007). $</$ jrn $>$

$<$ jrn>18. Beck, R. A., Burbank, D. W., Sercombe, W. J., Olson, T. L. \& Khan, A. M. Organic carbon exhumation and global warming during the early Himalayan collision. Geology 23, 387-390 (1995).</jrn> 
$<$ jrn $>$ 19. Pierson-Wickmann, A.-C., Reisberg, L., France-Lanord, C. \& Kudrass, H. Os$\mathrm{Sr}-\mathrm{Nd}$ results from sediments in the Bay of Bengal: Implications for sediment transport and the marine Os record. Paleoceanography 16, 435-444 (2001). $<$ jrn>

$<$ jrn $>20$. France-Lanord, C. \& Derry, L. A. $\delta^{13} \mathrm{C}$ of organic carbon in the Bengal Fan: Source evolution and transport of $\mathrm{C} 3$ and $\mathrm{C} 4$ plant carbon to marine sediments. Geochim. Cosmochim. Acta 58, 4809-4814 (1994). </jrn>

$<$ jrn $>21$. Freeman, K. H. \& Colarusso, L. A. Molecular and isotopic records of C4 grassland expansion in the late Miocene. Geochim. Cosmochim. Acta 65, 1439-1454 (2001). $</$ jrn $>$

$<\mathrm{edb}>22$. Meyers, P. A. \& Dickens, G. R. in Synthesis of Results from Scientific Drilling in the Indian Ocean (eds Duncan, R. A. et al.) 295-309 (Vol. 70, American Geophysical Union, 1992). $</$ edb $>$

$<$ jrn $>23$. Suckow, A., Morgenstern, U. \& Kudrass, H.-R. Absolute dating of recent sediments in the cyclone-influenced shelf area off Bangladesh: Comparison of gamma spectrometric $\left({ }^{137} \mathrm{Cs},{ }^{210} \mathrm{~Pb},{ }^{228} \mathrm{Ra}\right)$, radiocarbon, and ${ }^{32} \mathrm{Si}$ ages. Radiocarbon 43, 917-927 (2001).</jrn>

$<$ jrn $>24$. Cai, W.-J. \& Sayles, F. L. Oxygen penetration depths and fluxes in marine sediments. Mar. Chem. 52, 123-131 (1996). </jrn>

$<$ jrn $>25$. Schwenk, T., Spiess, V., Breitzke, M. \& Hubscher, C. The architecture and evolution of the Middle Bengal Fan in vicinity of the active channel-levee system imaged by high-resolution seismic data. Mar. Petrol. Geol. 22, 637-656 $(2005) .</ j \mathrm{jn}>$

<jrn>26. Weber, M. E., Wiedicke, M. H., Kudrass, H. R., Hübscher, C. \& Erlenkeuser, H. Active growth of the Bengal Fan during sea-level rise and highstand. Geology 25, 315-318 (1997). $<$ jirn>

$<$ jrn $>27$. Berner, U., Poggenburg, J., Faber, E., Quadfasel, D. \& Frische, A. Methane in ocean waters of the Bay of Bengal: Its sources and exchange with the atmosphere. Deep-sea Res. II 50, 925-950 (2003). </jrn>

$<$ jrn $>28$. Broecker, W. S., Toggweiler, J. R. \& Takahashi, T. The Bay of Bengal - A major nutrient source for the deep Indian Ocean. Earth Planet. Sci. Lett. 49, 506-512 $(1980) .</ \mathrm{jrn}>$ 
$<$ jrn $>29$. Goni, M. A. et al. Distribution and sources of particulate organic matter in the water column and sediments of the Fly River Delta, Gulf of Papua (Papua New Guinea). Estuar. Coast. Shelf Sci. 69, 225-245 (2006).</jrn>

Supplementary Information is linked to the online version of the paper at www.nature.com/nature.

Acknowledgements This study was funded by CNRS-INSU programmes Eclipse and Relief de la Terre. We thank A. Gajurel and M. Rahman for help during the sampling of river sediments; C. Guilmette for technical assistance in the stable isotopes laboratory; and P. Burnard and L. Reisberg for improving the quality of the text. This CRPG-CNRS contribution \#1882.

Author Contributions VG and CFL are the main authors and wrote the text. $\mathrm{OB}$ conducted the fossil $\mathrm{C}_{\text {org }}$ characterisation. PF and FP were involved in the organic geochemistry part of the study. HK provided the Bengal fan sediments and their sedimentological description.

Author Information Reprints and permissions information is available at www.nature.com/reprints. Correspondence and requests for materials should be addressed to V.G. (vgaly@whoi.edu or vgaly@crpg.cnrsnancy.fr).

Figure 1 Map of the Himalayan basin. Ganges, Brahmaputra and Lower Meghna (LM) were sampled in Bangladesh (open squares). The different parts of the Bengal fan were investigated using cores from cruise SO 93 (filled black circles and corresponding core numbers). The black line represents the modern active channel.

Figure 2 TOC of riverine sediments as a function of their $\mathrm{Al} / \mathrm{Si}$ ratio. Filled grey symbols, Brahmaputra; open symbols, Ganges; filled black symbols, Lower Meghna. TOC is very low in the sandy and quartz-enriched bed sediments (circles). In the suspended sediments (squares), TOC linearly increases with the relative proportion of aluminous fine-grained minerals. Sediments from the three rivers define comparable positive trends, indicating they have similar $\mathrm{C}_{\text {org }}$ loading relative to their composition. Best fit (solid line) and $95 \%$ confidence interval (dashed lines) are shown for Lower Meghna sediments.

Figure 3 Radiocarbon composition of acid-insoluble $C_{\text {org }}$ extracted from riverine depth profile sediments as a function of 1/TOC. Filled grey symbols, Brahmaputra; open symbols, Ganges; and filled black symbols, Lower Meghna. Circles, monsoon 2002; squares, monsoon 2004; diamonds, monsoon 2005. Sediments from each river define a mixing trend between bed sediment dominated by aged $\mathrm{C}_{\text {org }}$ and suspended sediments with higher TOC and dominated by modern $\mathrm{C}_{\mathrm{org}}$. Maximum $2 \sigma$ uncertainties on $\Delta{ }^{14} \mathrm{C}$ and TOC are respectively $5 \%$ and $0.03 \%$. 
Figure 4 TOC of riverine and fan sediments as a function of their Al/Si ratio. Filled black diamonds, TOC of the Bengal fan sediments, with best fit (solid line) and 95\% confidence interval (dashed lines). Marine sediments define a positive trend highly comparable to that defined by river sediments (filled grey squares), suggesting they have similar $\mathrm{C}_{\text {org }}$ loads.

\section{Methods}

\section{Sampling}

Detailed sampling of the Ganges, Brahmaputra and Lower Meghna was performed during the 2002, 2004 and 2005 monsoons in Bangladesh. On the basis of daily river survey data from the Bangladesh Water Development Board (BWDB), sediment flux during the monsoon is three orders of magnitude higher than during the dry season ${ }^{13}$. As a consequence, $\sim 95 \%$ of the sediment flux is transported during the monsoon, and suspended sediments sampled during the monsoon are therefore representative of the total sediment flux. Suspended sediments were taken at different depths in the river channel and bedload was dredged from the bottom of the river. The sampling was systematically performed in the main channel where the velocities are the highest. In 2005, we also performed a depth sampling in a low velocity zone close to the bank to improve the description of the whole river section. Sediments were sampled using a 5-1 Nalgene bottle, ballasted and equipped with a depth probe. At a given depth the bottle was opened, then lifted on board after filling. During filling, the depth slightly increases by about one metre; the average depth was recorded as the reference depth. The total contents of the bottle were carefully transferred into opaque plastic containers and sealed free of air. Samples were then filtered at $0.2 \mu \mathrm{m}$ through a $90 \mathrm{~mm}$ nitrile membrane. Special care was taken to recover particles adsorbed at the surface of the container. Suspended sediment concentrations were weighed for each sample. Major and trace element concentrations were measured by ICP-AES and ICP-MS at the Service d'Analyse des Roches et des Minéraux (CRPG-Nancy) on bulk sediment after lithium metaborate fusion.

Marine sediments were taken from short cores drilled in the Bengal fan by the RV

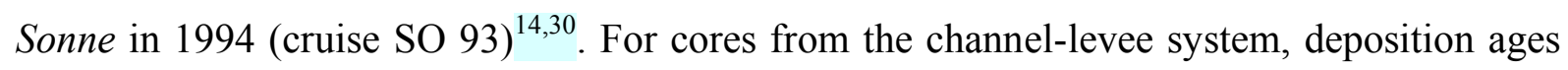
have been estimated on the basis of foraminifer ${ }^{14} \mathrm{C}$ ages and stable isotopes; sediments used in this study were deposited during the last glacial-interglacial cycle. Sediments from the Bengal shelf were dated using gamma-spectrometric and radiocarbon methods ${ }^{23}$. We used a sample set that covers the past $500 \mathrm{yr}$ of sedimentation, including modern samples. 


\section{Organic carbon analyses}

G-B river sediments as well as Bengal fan sediments contain significant amounts of detrital carbonates including dolomite ${ }^{31-33}$. $\mathrm{C}_{\text {org }}$ concentration and isotopic measurements must therefore be performed on decarbonated sediments. Efficient dolomite dissolution was achieved through $1 \mathrm{~h}$ leaching with $4 \mathrm{wt} \% \mathrm{HCl}$ at $80^{\circ} \mathrm{C}$. After $50{ }^{\circ} \mathrm{C}$ oven drying, the $\mathrm{C}_{\text {org }}$ content was determined either by elemental analysis on a EuroVector EuroEA3028-HT or by conventional $\mathrm{CuO}$ combustion $^{20}$. The problem with aqueous acid leaching is that an unknown proportion of $\mathrm{C}_{\text {org }}$ is solubilized by acid hydrolysis. For a representative set of river and marine sediments, the amount of $\mathrm{C}_{\text {org }}$ solubilized during the decarbonatation was measured in order to obtain the real TOC. $\mathrm{C}_{\text {org }}$ content measured after decarbonation and TOC define a very good linear correlation (Supplementary Fig. 6). We used this relationship to calculate TOC for each sample from $\mathrm{C}_{\text {org }}$ content measured after decarbonation. The overall $2 \sigma$ uncertainty associated with the TOC determination is $0.03 \%$.

$\Delta^{14} \mathrm{C}$ were also determined on decarbonated fractions. Acid-insoluble $\mathrm{C}_{\text {org }}$ was converted into pure $\mathrm{CO}_{2}$ at $\mathrm{CRPG}$ (Nancy) following the conventional $\mathrm{CuO}$ combustion method ${ }^{20} .{ }^{14} \mathrm{C}$ measurements were performed on the LMC14 (Gif sur Yvette) AMS national facility. Maximum overall uncertainty on $\Delta^{14} \mathrm{C}$ calculations was estimated to be $5 \%$.

Soluble $\mathrm{C}_{\text {org }}$ was extracted from bulk sediments with dichloromethane using an Accelerated Solvent Extractor (ASE 200). n-alkane relative abundances were determined on a HP 5890 GC-MS and compound specific $\delta^{13} \mathrm{C}$ was measured on a GV-Isoprime GC-IRMS.

\section{Raman spectroscopy and HRTEM}

Raman spectra were obtained with a Renishaw INVIA Reflex Raman micro-spectrometer at the Laboratoire de Géologie of the Ecole Normale Supérieure, Paris, France. Spectra were excited at room temperature with the $514.5 \mathrm{~nm}$ line of a $20 \mathrm{~mW}$ Ar Spectra Physics laser through a LEICA 50X long-working distance objective (NA 0.50). The laser spot at the sample surface had a diameter of approximately $3 \mu \mathrm{m}$ and a power of $1 \mathrm{~mW}$, which should be low enough to avoid any spectral change or sample destruction due to light absorption and local temperature increase ${ }^{34}$. Light was dispersed by a holographic grating with 1,800 grooves $\mathrm{mm}^{-1}$. The spectral resolution of about $1.4 \mathrm{~cm}^{-1}$ was determined by measuring a neon lamp emission. The spectrometer was calibrated for every session by measuring the position of the neon lamp emission and/or a silicon wafer. The dispersed light was collected by a RENCAM CCD detector. The synchroscan mode from 100 to $2,000 \mathrm{~cm}^{-1}$ was selected in order to retrieve Raman modes from both carbonaceous matter $\left(C M ; 1,300-1,600 \mathrm{~cm}^{-1}\right.$ 
region) and silicates/carbonates $\left(100-1,100 \mathrm{~cm}^{-1}\right)$. Raman investigations were directly performed on the raw samples, without any preparation. The first-order Raman spectrum of disordered $\mathrm{CM}$ exhibits a graphite $\mathrm{G}$ band at $1,580 \mathrm{~cm}^{-1}$, corresponding to in-plane vibration of aromatic carbons, and several defect bands (including the most important at $1,350 \mathrm{~cm}^{-1}$ ), corresponding to physico-chemical defects ${ }^{35}$.

HRTEM was performed on a JEOL 2010 microscope with an acceleration voltage of $200 \mathrm{kV}$. Low- and high-magnification observations as well as electron diffraction were conducted on river and oceanic sediment samples. In particular, the high-magnification 002 lattice fringes mode was used to image directly the aromatic skeleton of CM together with selected area electron diffraction to detect the presence of triperiodic graphite. For HRTEM investigations, $\mathrm{CM}$ was concentrated from river and marine sediments using $\mathrm{HCl} / \mathrm{HF}$ acid treatment at low temperature (always below $70^{\circ} \mathrm{C}$ ). More details regarding the sample preparation and transmission electron microscopy analysis of natural solid CM may be found in ref. 35 and references therein.

$<$ unknown>30. Kudrass, H. Bengal Fan (Sonne cruise 93 final report, 1996). $<$ /unknown>

$<$ bok>31. Cochran, J. R., Stow, D.A.V., et al.,Proc. ODP, Init. Repts., vol 116, 388, $(1989) .</$ bok $>$

$<$ jrn $>$ 32. Galy, A., France-Lanord, C. \& Derry, L. A. The strontium isotopic budget of Himalayan rivers in Nepal and Bangladesh. Geochim. Cosmochim. Acta 63, 19051925 (1999). $<$ jrn $>$

$<$ bok $>33$. von der Borch, C. C, Sclater, John G.. et al. Initial report of the Deep Sea Drilling Project Vol. 22 (US Government Printing Office, Washington, 1974).</bok $>$

$<$ jrn $>34$. Beyssac, O. et al. On the characterisation of disordered and heterogenous carbonaceous materials by Raman spectroscopy. Spectrochim. Acta A 59, 2267-2276 $(2003) .</ j \mathrm{jn}>$

$<$ jrn $>35$. Beyssac, O., Rouzaud, J.-N., Goffé, B., Brunet, F. \& Chopin, C. Graphitization in a high-pressure, low temperature gradient: A Raman microspectroscopy and HRTEM study. Contrib. Mineral. Petrol. 143, 19-31 (2002). </jrn> 


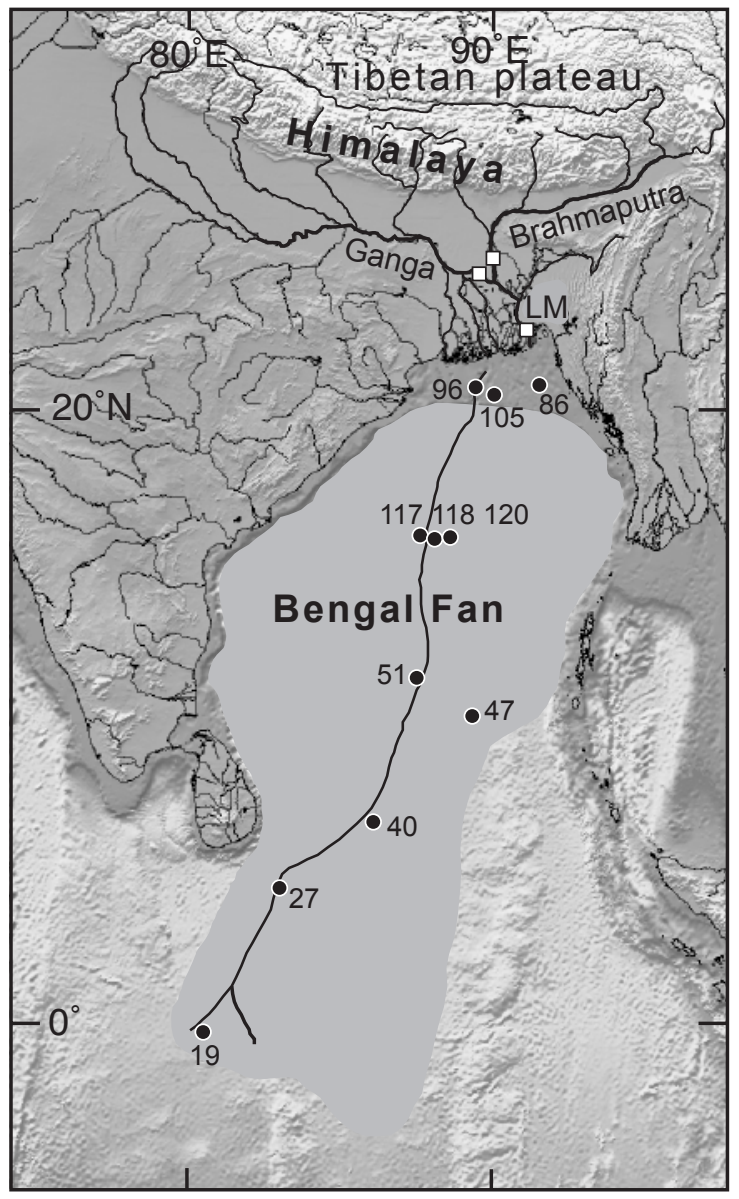


Figure 2

Galy et al.

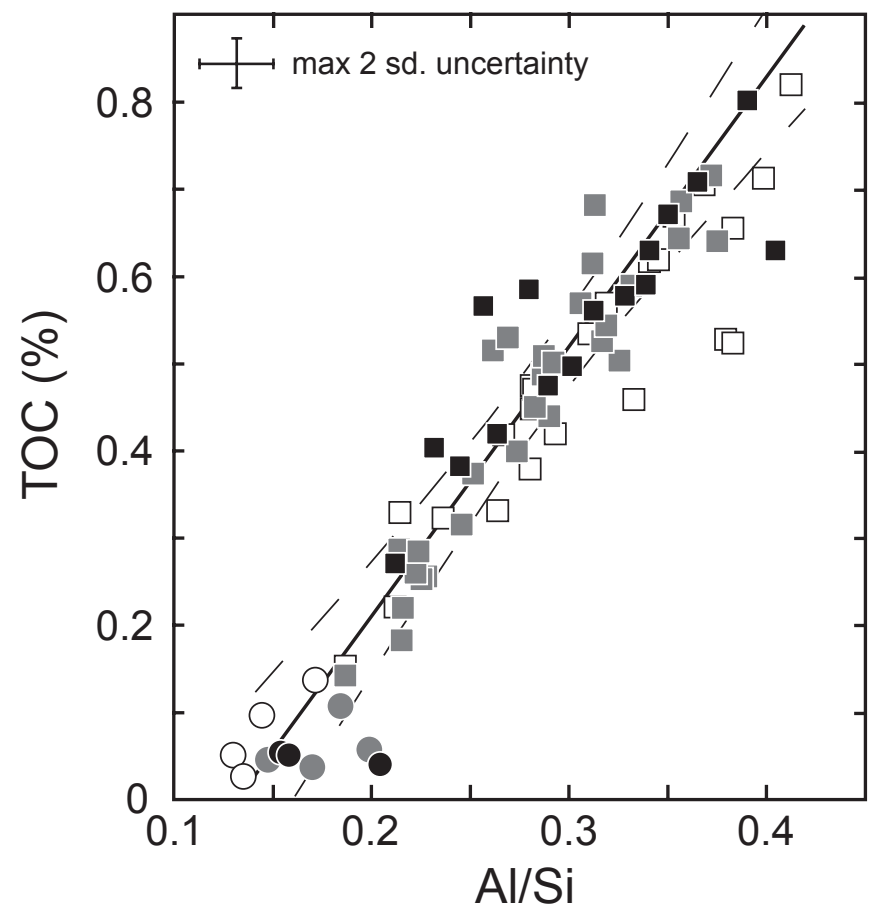


Figure 3

Galy et al.

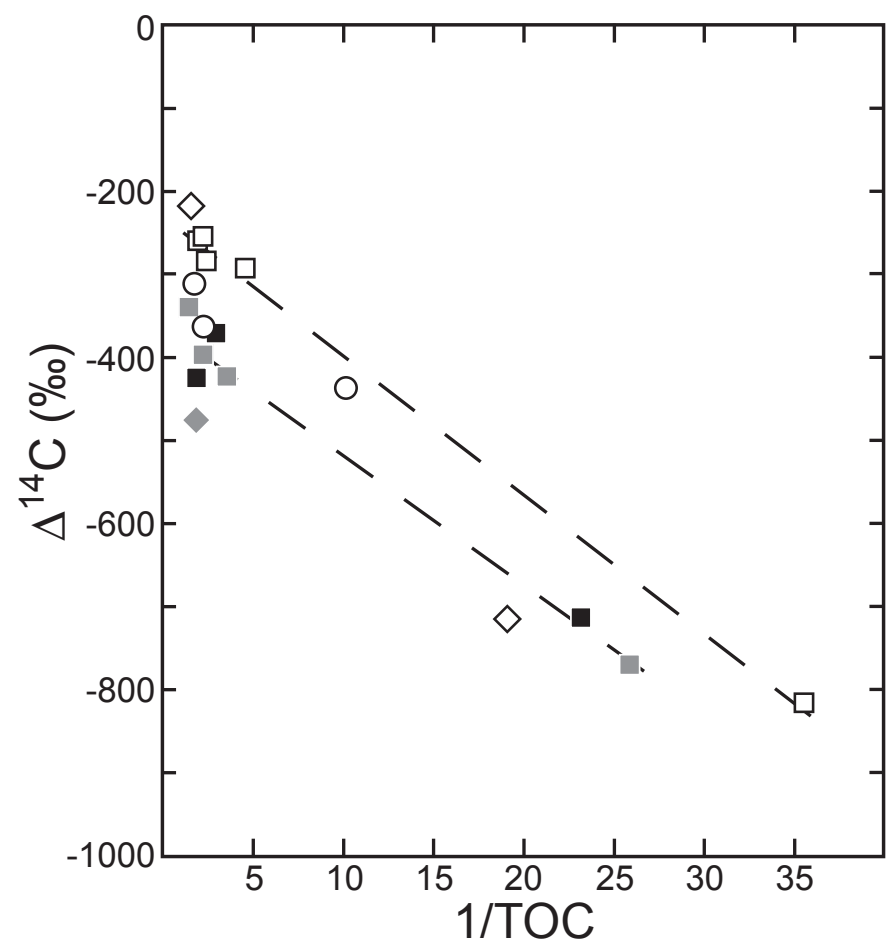


Figure 4

Galy et al.

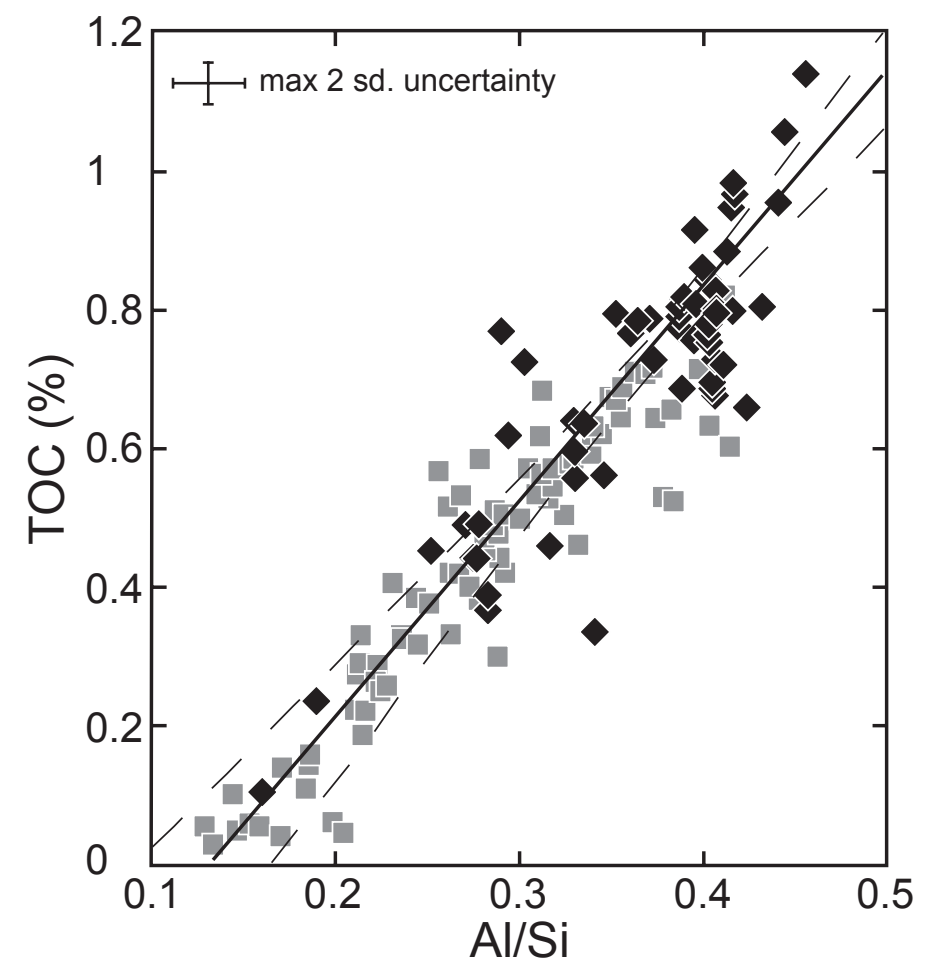

